\title{
ANALISIS EFESIENSI DAN IDENTIFIKASI FAKTOR SOSIAL, EKONOMI DAN TEKNIS YANG MEMPENGARUHI KONVERSI USAHATANI JERUK KE USAHATANI KOPI DI KECAMATAN BARUSJAHE KABUPATEN KARO
}

\author{
Albina Ginting ${ }^{1}$, Hotden L. Nainggolan ${ }^{1}$, Musfrianto H. Ginting ${ }^{1}$
}

Email Author: hotdenleonardo76@gmail.com

\begin{abstract}
The aim of this study are; a) to determine the efficiency level of citrus farming and conversion to coffee farming in Barusjahe District, b) to identify social, economic and technical factors affecting conversion of citrus farming to coffee farming in Barusjahe District, and this research uses descriptive data analysis method. The results of research are; a) average income level of citrus farming Rp. 14,867,110/ha/ year < average income of coffee farming Rp.17.675.996/ha/ year, and efficiency of citrus farming (R/ C: 2.52) $<$ efficiency of coffee farming (R/C: 4,43), b) Social factor that is public acknowledgment is the main reason of $33 \%$ of respondents to convert citrus farming to coffee farming. And the economic factor that is the price is the main reason $33.3 \%$ respondents, the conversion of citrus farming to coffee farming. As well as technical factors namely the maintenance process is the main reason for $56.67 \%$ of farmers respondents to convert citrus farming to coffee farming in Barusjahe District. Based on the research results suggested; a) for the government to conduct continuous counseling for farmers of coffee farming so that its production is increasing, b) so that citrus farmers do better maintenance and maintenance in order to optimize their production, c) so that farmers use pesticide in accordance with recommended dosage, to reduce the cost pesticides, d) for farmers to pay attention to the concept of sustainable agriculture in converting land from citrus farming to coffee farming in Barusjahe District so farmers' income can be sustainable.
\end{abstract}

Keywords: income, efficiency, coffee farming, citrus farming

\section{PENDAHULUAN}

Salah satu yang menjadi syarat mutlak keberhasilan pembangunan pertanian adalah penerapan teknologi yang senantiasa berubah. Penggunaan teknologi dalam usahatani sangat dibutuhkan petani untuk meningkatkan produktivitas, peningkatan efisiensi usaha, menaikkan nilai tambah serta meningkatkan pendapatan petani. Kenyataan saat ini banyak petani yang belum sepenuhnya menerapkan teknologi dalam usahatani. Hal ini disebabkan kurangnya pengetahuan petani tentang teknologi pertanian, disamping latar belakang sosial dan ekonomi, budaya juga dapat mempengaruhi cepat atau lambatnya inovasi diterima petani itu sendiri (Lubis, 2010).

Keterbatasan teknologi yang dibarengi dengan rendahnya pendidikan petani membuat pola produksi pertanian menjadi sangat sederhana sehingga tidak menghasilkan produksi yang optimal. Pengelolaan usahatani secara tradisional merupakan indikasi lemahnya kualitas sumber daya manusia (SDM) sektor pertanian, maka diperlukan upaya pembinaan dan penyuluhan secara kontinu. Rendahnya kualitas tenaga kerja tidak hanya mengakibatkan rendahnya produktivitas dan pendapatan, tetapi juga menyulitkan

\footnotetext{
${ }^{1}$ Staff Pengajar Program Studi Agribisnis Fakultas Pertanian Universitas HKBP Nommensen
} 
pemanfaatan sumber daya alam yang melimpah secara optimal.

Disamping itu lahan usahatani juga merupakan faktor penting bagi pengembangan komoditas pertanian. Luas lahan akan mempengaruhi skala usaha dan tingkat efisiensi usahatani (Dwipradnyana $d k k$, 2015). Lahan sebagai salah satu faktor produksi mempunyai kontribusi cukup besar terhadap usahatani. Perbedaan status kepemilikan lahan juga berpengaruh terhadap suksesnya sistem pertanian (Salikin, 2003). Petani yang memiliki lahan yang lebih luas akan lebih mudah menerapkan inovasi dibandingkan dengan petani berlahan sempit. Hal ini disebabkan keefektifan dan efisiensi dalam penggunaan sarana produksi (Soekartawi, 2003). Dan petani yang mempunyai lahan yang lebih luas akan lebih mudah menerapkan anjuran penyuluhan dan adopsi inovasi teknologi dari pada yang memiliki lahan sempit (Kusuma, 2006).

Propinsi Sumatera Utara merupakan salah satu wilayah di Indonesia yang merupakan sentra pengembangan tanaman hortikultura dan perkebunan rakyat, dan komoditi ini tersebar hampir disemua wilayah kabupaten/kota. Kabupaten Karo merupakan salah satu wilayah sebagai sentra produksi hortikultura dan perkebunan rakyat di Sumatera Utara. Tanaman perkebunan yang dibudidayakan masyarakat, antara lain; komoditi kopi, untuk tanaman hortikultura (buah-buahan) antara lain; komoditi jeruk.

Komoditi jeruk merupakan salah satu komoditas hortikultura yang sudah lama dikembangkan masyarakat di Kabupaten Karo. Jeruk merupakan buahbuahan yang digemari masyarakat baik sebagai buah segar maupun olahan. Buah ini dapat dikonsumsi segenap lapisan masyarakat mulai dari yang berpendapatan rendah hingga yang berpendapatan tinggi.

Teknis pemeliharaan usahatani jeruk secara umum tidak mudah sehingga membutuhkan pola pengelolaan yang baik, sehingga membutuhkan inovasi dan sentuhan teknologi agar produksi yang dihasilkan maksimal. Pada satu sisi sarana produksi seperti; pupuk dan obat-obatan masih tergolong mahal di Kabupaten Karo, sehingga petani membutuhkan modal yang tinggi (biaya produksi tinggi) yang berakibat pada rendahnya pendapatan usahatani jeruk.

Pemberian pupuk berimbang dan pestisida secara teratur dan berkala merupakan hal penting dalam meningkatkan produksi usahatani jeruk, dan masih terdapat faktor lain yang turut menentukan peningkatan produksi dan pendapatan petani dari usahatani jeruk antara lain; luas lahan, harga ditingkat petani, saluran distribusi dan lain sebagainya. (2016) menunjukkan terjadi trend penurunan luas lahan usahatani jeruk hampir di semua kecamatan di Kabupaten Karo yang diikuti dengan fluktuasi poroduksinya, salah satunya adalah di Kecamatan Barusjahe Kabupaten Karo, sebagaimana pada Tabel. 1. 
Tabel 1. Perkembangan Luas Lahan (ha) dan Produksi Jeruk (ton) di Kecamatan Barusjahe Tahun 2012-2016

\begin{tabular}{lrrrr}
\hline Tahun & Luas lahan (ha) & $+/$ - luas lahan $(\%)$ & Produksi (ton) & + -- produksi (\%) \\
\hline 2012 & 434 & 0 & 14.714 & 0 \\
\hline 2013 & 394 & $-0,9$ & 11.383 & $-0,7$ \\
\hline 2014 & 765 & 1,9 & 16.534 & 1,4 \\
\hline 2015 & 312 & $-0,4$ & 14.281 & $-0,8$ \\
\hline 2016 & 283 & $-0,9$ & 13.776 & $-0,9$ \\
\hline
\end{tabular}

Sumber : BPS, Kecamatan Barusjahe Dalam Angka, 2016

Tabel 1 menunjukkan terjadi penurunan luas lahan jeruk tertinggi di Kecamatan Barus Jahe pada tahun 2016 yaitu turun $0,9 \%$ dari tahun 2015 menjadi 283 ha, yang dikuti dengan penurunan produksi dari tahun 2015 sebesar $0,9 \%$ menjadi 13.776 ton pada tahun 2016.

Data BPS Kabupaten Karo (2016) juga menunjukkan terjadi tend pertambahan luas lahan komoditi kopi di wilayah ini. Data ini menunjukkan Kabupaten Karo merupakan salah satu daerah penghasil kopi di Propinsi Sumatera Utara. Komoditi kopi yang umum diusahakan petani adalah jenis kopi arabika, dan produk kopi ini telah memiliki tingkat permintaan yang sangat besar hingga ke luar negeri.
Kopi merupakan komoditas perkebunan yang mempunyai peran penting dalam kegiatan perekonomian daerah. Hal ini karena komoditi kopi berperan sebagai penyedia lapangan kerja dan sumber pendapatan bagi petani maupun bagi pelaku ekonomi lainnya yang terlibat dalam budidaya, pengolahan, maupun dalam mata rantai pemasaran (Thamrin $d k k, \quad 2015$. Usahatani kopi berkembang hampir di semua kecamatan di Kabupaten Karo, mengingat topografi wilayah yaitu; jenis tanah, iklim, ketinggian tempat dan suhu sangat mendukung pertumbuhan komoditi kopi. Salah satunya adalah di Kecamatan Barusjahe sebagaimana disajikan pada Tabel 2.

Tabel 2. Perkembangan Luas Lahan (ha) dan Produksi Kopi (ton) di Kecamatan Barusjahe Tahun 2012-2016.

\begin{tabular}{lrrrr}
\hline Tahun & Luas lahan (ha) & +/- luas lahan (\%) & Produksi (ton) & +/- produksi (\%) \\
\hline 2012 & 462 & 0 & 336,67 & 0 \\
\hline 2013 & 292 & $-0,6$ & 314,15 & $-0,9$ \\
\hline 2014 & 1.291 & 4,4 & 1.768 & 5,6 \\
\hline 2015 & 1.291 & 0 & $1.502,8$ & $-0,8$ \\
\hline 2016 & 1.341 & 1,03 & 3.202 & 2,1 \\
\hline
\end{tabular}

Sumber : BPS, Kecamatan Barusjahe Dalam Angka, 2016

Tabel 2 menunjukkan tahun 2014 terjadi pertumbuhan luas lahan komoditi kopi yang sangat besar di Kecamatan Barusjahe yaitu 4,4\% dari tahun 2013 dengan luas lahan 1,292 ha dengan produksi 1.768 ton, atau naik $5,6 \%$ dari tahun sebelumnya Berdasarkan Tabel 1 yang menunjukkan trend kecendrungan penurunan luas lahan usahatani jeruk dan Tabel 2 
menunjukkan trend pertambahan luas lahan usahatani kopi di Kecamatan Baru Jahe Kabupaten Karo, dimungkinkan telah terjadi alih fungsi lahan/ konversi dari satu jenis usahatani ke jenis usahatani lain atau terjadi perubahan pola usahatani (Barati et al, 2015) sebagaimana yang disampaikan Tambunan (2003), pola kegiatan usahatani dipengaruhi oleh beberapa faktor dan salah satu faktor yang mempengaruhinya adalah faktor sosial (Home et al, 2015) dan faktor ekonomi petani yang meliputi; umur, tingkat pendidikan, pengalaman usahatani, jumah tanggungan keluarga dan kepemilikan lahan, dengan demikian tujuan penelitian ini adalah untuk "mengetahui efisiensi dan identifikasi faktor sosial, ekonomi dan teknis yang mempengaruhi konversi usahatani jeruk ke usahatani kopi di Kecamatan Barusjahe Kabupaten Karo".

\section{METODE PENELITIAN}

\section{Lokasi dan Sampel Penelitian}

Penelitian ini dilakukan Kecamatan Barusjahe yang dipilih secara purposive dimana daerah ini merupakan salah satu kecamatan yang menghasilkan komoditi jeruk dan komoditi kopi di Kabupaten Karo, Propinsi Sumatera Utara. Sampel pada penelitian ini ditentukan sebanyak 30 responden yang mengkonversi sebagian usahatani jeruk ke usahatani kopi pada 3 desa yaitu Desa Sukanalu dengan populasi $1.530 \mathrm{kk}$ (10 sampel), Desa Sukajulu dengan populasi $880 \mathrm{kk}$ (10 sampel), dan Desa Barusjahe dengan populasi $705 \mathrm{kk}$ (10 sampel), dan ketiga desa tersebut mewakili 19 desa yang ada di Kecamatan Barusjahe Kabupaten Karo.

\section{Data dan Metode Analisis Data}

Data yang digunakan pada penelitian ini adalah data primer dan sekunder. Data primer diperoleh dari lapangan melalui wawancara langsung kepada petani yang mengkonversi sebagian usahatani jeruknya ke usahatani kopi di Kecamatan Barusjahe. Data sekunder diperoleh dari instansi terkait yaitu Badan Pusat Statistik Kabupaten Karo, Dinas Pertanian Kabupaten Karo dan Badan Pusat Statistik Kecamatan Barusjahe. Data pada penelitian ini dianalisis dengan metode deskriptif.

\section{HASIL DAN PEMBAHASAN}

\section{Karakteristik Petani Responden}

Berdasarkan hasil penelitian diketahui karakteristik petani responden di daerah penelitian Kecamatan Barusjahe. Karaktaeristik petani responden tersebut meliputi; umur petani, tingkat pendidikan dan karakteristik luas lahan yang dikelola petani sebagaimana disajikan pada Tabel 3. 
Tabel 3. Karekteristik Petani Responden yang Melakukan Konversi Usahatani Jeruk ke Usahatani Kopi Berdasarkan Kelompok Umur, Tingkat Pendidikan dan Luas lahan yang diusahakan di Kecamatan Barusjahe, Tahun 2017.

\begin{tabular}{|c|c|c|c|c|}
\hline No & Karakteristik & & Jumlah responden (orang) & Persentase $(\%)$ \\
\hline 1 & \multirow{2}{*}{$\begin{array}{l}\text { Kelompok umur } \\
\text { (tahun) }\end{array}$} & $<40$ thn & 3 & $10 \%$ \\
\hline 2 & & 41 thn $<$ & 27 & $90 \%$ \\
\hline Jumlah & & & 30 & $100 \%$ \\
\hline 3 & \multirow{4}{*}{$\begin{array}{l}\text { Tingkat } \\
\text { pendidikan }\end{array}$} & SD & 4 & $13,33 \%$ \\
\hline 4 & & SMP & 13 & $43,33 \%$ \\
\hline 5 & & SMA & 13 & $43,33 \%$ \\
\hline 6 & & S1 & 0 & $0 \%$ \\
\hline Jumlah & & & 30 & $100 \%$ \\
\hline 7 & \multirow{5}{*}{ Luas lahan (ha) } & $<1$ & 4 & $13,33 \%$ \\
\hline 8 & & $1,1-1,5$ & 15 & $50 \%$ \\
\hline 9 & & $1,6-2$ & 6 & $20 \%$ \\
\hline 10 & & $2,1-2,5$ & 2 & $6,67 \%$ \\
\hline 11 & & $2,6<$ & 3 & $10 \%$ \\
\hline Jumlah & & & 30 & $100 \%$ \\
\hline
\end{tabular}

Sumber : Data Primer, diolah 2017

Tabel 3 menunjukkan umur petani responden pada daerah penelitian dibagi kedalam 2 kelompok umur yaitu kelompok umur $<40$ tahun dan kelompok umur > 41 tahun. Hasil penelitian menunjukkan $90 \%$ responden di daerah penelitian memiliki tingkat umur diatas 41 tahun, dan 10\% responden yang memiliki umur dibawah 40 tahun, hal ini menunjukkan bahwa petani responden sudah lama bertani diwilayah ini.

Berdasarkan Tabel 3 dapat dilihat tingkat pendidikan petani responden di daerah penelitian dikelompokkan menjadi 4 (empat) kelompok yaitu: SD, SMP, SMA dan S1. Tabel 3 menunjukkan 13,33\% petani responden didaerah penelitian memiliki tingkat pendidikan SD. Kemudian 43,33\% petani responden memiliki tingkat pendidikan SMP dan 43,33\% responden memiliki tingkat pendidikan SMA, hal ini menunjukkan bahwa umumnya petani di daerah penelitian masih berpendidikan SMP dan SMA.
Tabel 3 juga menunjukkan jumlah responden di daerah penelitian berdasarkan luas lahan, yaitu; 13,33\% responden memiliki luas lahan $<1$ ha, $20 \%$ responden memiliki luas lahan 1,62 ha, $6,67 \%$ responden memiliki luas lahan 2,1-2,5 ha, dan responden memiliki luas lahan diatas 2,6 ha sebesar 10\%. Hal ini menunjukkan bahwa umumnya responden atau sebesar $50 \%$ didaerah penelitian memiliki luas lahan $1,1-1,5$ ha.

\section{Biaya Produksi, Penerimaan dan Pendapatan Usahatani Jeruk dan Usahatani Kopi Hasil Konversi di Kecamatan Barusjahe \\ 2.1. Biaya Produksi Usahatani Jeruk dan Usahatani Kopi Hasil Konversi di Kecamatan Barusjahe}

Berdasarkan hasil penelitian diketahui biaya produksi usahatani jeruk dan biaya produksi usahatani kopi hasil 
konversi di daerah penelitian Kecamatan

Barusjahe sebagaimana pada Tabel 4.

Tabel 4. Biaya Produksi Rata-rata Usahatani Jeruk dan Usahatani Kopi (per tahun) di Kecamatan Barusjahe, 2017

\begin{tabular}{llrr}
\hline \multirow{2}{*}{ No } & \multirow{2}{*}{ Keterangan } & \multicolumn{2}{c}{ Biaya produksi rata-rata (Rp)/ha/tahun } \\
\cline { 3 - 4 } & & Usahatani jeruk & Usahatani kopi \\
\hline \multirow{2}{*}{2} & Biaya Peralatan & 3.650 .950 & 518.267 \\
\hline 3 & Tenaga Kerja & 1.790 .133 & 1.091 .667 \\
\hline 4 & Pupuk & 3.535 .900 & 2.950 .700 \\
\hline \multicolumn{2}{l}{ Total } & 785.657 & 581.203 \\
\hline
\end{tabular}

Sumber : Data Primer, diolah 2017

Berdasarkan Tabel 4 diketahui rata-rata biaya peralatan yang dikeluarkan petani untuk usahatani kopi Rp.3.650.950/ha/ tahun, biaya rata-rata upah tenaga kerja adalah Rp1.790.133/ ha/ tahun, biaya rata-rata untuk pupuk Rp.3.535.900 ha/ tahun, dan rata-rata biaya pestisida Rp.785.657 ha/ tahun, sehingga rata-rata total biaya produksi usahatani jeruk Rp.9.762.640/ ha/ tahun.

Sementara itu berdasarkan Tabel 4 juga diketahui rata-rata biaya peralatan untuk usahatani kopi hasil konversi adalah Rp.518.267/ ha/ tahun, rata-rata biaya upah tenaga kerja Rp.1.091.667/ ha/ tahun, biaya rata-rata untuk pupuk
2.950.700 ha/ tahun, sehingga rata-rata total biaya produksi untuk usahatani kopi hasil konversi Rp.5.141.837/ha/tahun.

\subsection{Penerimaan Usahatani Jeruk dan Usahatani Kopi Hasil Konversi di Kecamatan Barusjahe}

Menurut Soekartawi (2003) penerimaan adalah jumlah produksi yang diperoleh dari kegiatan usahatani dikalikan dengan harga berlaku. Ratarata penerimaan usahatani jeruk dan usahatani kopi hasil konversi pada daerah penelitian Kecamataan Barusjahe disajikan pada Tabel 5 .

Tabel 5.Penerimaan Rata-rata Usahatani Jeruk dan Usahatani Kopi (per tahun) di Kecamatan Barusjahe, 2017

\begin{tabular}{llrr}
\hline \multirow{2}{*}{ No } & \multirow{2}{*}{ Keterangan } & \multicolumn{2}{c}{ Rata-rata Penerimaan (Rp) } \\
\cline { 3 - 4 } & & Usahatani jeruk & Usahatani kopi \\
\hline 1 & Luas lahan (ha) & 0,55 & 0,91 \\
\hline 2 & Produksi (Kg) & 5.963 & $1.118,87$ \\
\hline 3 & Harga (Rp) & 4.133 & 20.433 \\
\hline 4 & Penerimaan (Rp/ha/tahun) & 24.629 .750 & 22.817 .833 \\
\hline
\end{tabular}

Sumber : Data Primer, diolah 2017

Berdasarkan Tabel 5 diketahui rata-rata luas lahan yang dimiliki petani untuk usahatani jeruk adalah 0,55 ha, dengan rata-rata produksi $5.963 \mathrm{~kg}$, dan rata-rata penerimaan petani $\mathrm{Rp}$. 24.629.750/ ha/ tahun. Tabel 5 juga menunjukkan rata-rata luas lahan usahatani kopi hasil konversi sebesar 0,91 ha, dengan rata-rata produksi $1.118,87 \mathrm{~kg}$, dan rata-rata penerimaan petani responden sebesar Rp. 22.817.833/ ha/ tahun. 


\subsection{Pendapatan Petani Usahatani Jeruk dan Usahatani Kopi Hasil Konversi di Kecamatan Barusjahe}

Berdasarkan hasil penelitian dan
analisis data diketahui tingkat pendapatan petani dari usahatani jeruk dan usahatani kopi hasil konversi sebagaimana disajikan pada Tabel 6 .

Tabel 6. Pendapatan Rata-rata Responden Petani Jeruk dan Responden Petani Kopi Hasil Konversi di Kecamatan Barusjahe Tahun 2017

\begin{tabular}{llrr}
\hline \multirow{2}{*}{ No } & \multirow{2}{*}{ Keterangan } & \multicolumn{2}{c}{ Rata-rata Pendapatan (Rp)/ha/tahun } \\
\cline { 3 - 4 } & & Usahatani jeruk & Usahatani kopi \\
\hline 1 & Biaya produksi & 9.762 .640 & 5.141 .837 \\
2 & Penerimaan & 24.629 .750 & 22.817 .833 \\
3 & Pendapatan & 14.867 .110 & 17.675 .996 \\
\hline
\end{tabular}

Sumber : Data Primer, diolah, 2017

Berdasarkan Tabel 6 diketahui rata-rata biaya produksi usahatani jeruk Rp.9.762.640/ ha/ tahun, dengan ratarata penerimaan Rp.24.629.750/ ha/tahun. Dengan demikian rata-rata pendapatan petani Rp. 14.867.110/ ha/tahun. Pada Tabel 6 juga dapat dilihat rata-rata biaya produksi usahatani kopi yaitu Rp.5.141.837 dengan rata-rata penerimaan Rp.22.817.833/ha/tahun. Dengan demikian rata-rata pendapatan petani Rp.17.675.996/ha/tahun.

\section{Efisiensi Usahatani Jeruk dan Usahatani Kopi Hasil Konversi di Kecamatan Baru Jahe}

Efisiensi usahatani merupakan suatu indikator yang menunjukkan bahwa penggunaan faktor-faktor produksi usahatani sudah maksimal, yang dapat diukur dari nilai $\mathrm{R} / \mathrm{C}$ ratio, jika semakin tinggi nilai $\mathrm{R} / \mathrm{C}$ usahatani dapat dikatakan usahatani semakin efisien.

Efisiensi juga dikaitkan dengan perbandingan biaya dengan output usahatani. Apabila output usahatani yang diterima petani lebih besar dari biaya yang digunakan akan mencerminkan tingkat resiko usahatani yang semakin minimal. Efisiensi usahatani jeruk dan usahatani kopi hasil konversi didaerah penelitian Kecamatan Barujahe sebagaimana pada Tabel 7.

Tabel 7. Tingkat Efisiensi Usahatani Jeruk dan Usahatani Kopi Hasil Konversi di Kecamatan Barusjahe, 2017

\begin{tabular}{llrr}
\hline \multirow{2}{*}{ No } & \multirow{2}{*}{ Keterangan } & \multicolumn{2}{c}{ Tingkat efisiensi (R/C) } \\
\cline { 3 - 4 } 1 & Penerimaan & Usahatani jeruk & Usahatani kopi \\
\hline 2 & Biaya produksi & 9.7629 .750 & 22.817 .833 \\
\hline 3 & R/C & 2,52 & 5.141 .837 \\
\hline
\end{tabular}

Sumber : Data Primer diolah, 2017

Tabel 7 menunjukkan bahwa usahatani jeruk memiliki nilai $\mathrm{R} / \mathrm{C}$ sebesar 2,52, dengan demikian usahatani ini dikatakan efisien karena nilai $\mathrm{R} / \mathrm{C}$ lebih besar dari 1 dan layak untuk diusahakan. Jika petani mengeluarkan 
biaya produksi untuk usaatani jeruk sebesar Rp. 1, akan mendapatkan penerimaan sebesar Rp. 2,52.

Tabel 7 juga menunjukkan bahwa tingkat efisiensi usahatani kopi sangat baik dengan nilai $\mathrm{R} / \mathrm{C} \quad 4,43$, artinya usahatani kopi di daerah penelitian Kecamatan Barusjahe efisien karena $\mathrm{R} / \mathrm{C}>1$, dimana jika petani mengeluarkan biaya Rp.1, akan mendapatkan penerimaan Rp. 4,43. Berdasarkan Tabel 7 diketahui nilai R/C usahatani kopi lebih besar daripada R/C usahatani jeruk di Kecamatan Barusjahe Kabupaten Karo, hal ini merupakan salah satu penyebab terjadinya alih fungsi lahan dari usahatani jeruk ke usahatani kopi di wilayah ini.
4. Faktor Sosial, Ekonomi dan Teknis yang Mempengaruhi Konversi Usahatani Jeruk ke Usahatani Kopi di Kecamatan Barusjahe Kabupaten Karo

\subsection{Faktor Sosial Yang Mempengaruhi Konversi Usahatani Jeruk ke Usahatani Kopi di Kecamatan Barusjahe Kabupaten Karo}

Hasil penelitian menunjukkan petani responden melakukan konversi usahatani jeruk ke usahatani kopi didasari pada berbagai faktor diantaranya; faktor sosial sebagaimana disajikan pada Tabel 8 .

Tabel 8. Pendapat Responden Tentang Faktor Sosial Sebagai Salah Satu Faktor yang Mempengaruhi Konversi Usahatani Jeruk ke Usahatani Kopi di Kecamatan Barusjahe 2017

\begin{tabular}{llrr}
\hline No & Faktor Sosial & Jumlah Responden & Persentase (\%) \\
\hline 1 & Tingkat pendidikan & 3 & 10 \\
\hline 2 & Pengalaman & 6 & 20 \\
\hline 3 & Kegiatan adat-istiadat (alokasi waktu) & 8 & 26,67 \\
\hline 4 & Kesehatan & 3 & 10 \\
\hline 5 & Pengakuan publik & 10 & 33,33 \\
\hline Jumlah & 30 & 100 \\
\hline
\end{tabular}

Sumber : Data Primer, diolah 2017

Berdasarkan Tabel 8 dapat dijelaskan bahwa $33,33 \%$ responden menyampaikan bahwa faktor sosial yaitu pengakuan publik merupakan hal utama yang menyebabkan petani melakukan konversi usahatani jeruk ke usahatani kopi. Pengakuan publik ini merupakan persepsi publik atau masyarakat bahwa usahatani kopi lebih prospektif diandingkan dengan usahatani jeruk, yang dilihat dari harga harapan (harga ekspektasi), lebih tahan terhadap serangan hama dan penyakit dan proses dipeliharaan tanaman kopi lebih mudah.
Kemudian 26,67\% responden menyampaikan bahwa faktor sosial yaitu alokasi waktu untuk kegiatan adatistiadat menjadi alasan kedua yang menyebabkan petani melakukan konversi usahatani jeruk ke usahatani kopi. Kegiatan adat-istiadat yang dimaksud adalah alokasi waktu yang diperlukan petani untuk mengikuti kegiatan adat istiadat lebih banyak jika mengusahakan usahatani kopi, karena usahatani ini tidak memerlukan pengontrolan yang ketat seperti usahatani jeruk dan 20\% responden mengatakakan bahwa faktor sosial berupa pengalaman juga merupakan 
faktor yang mempengaruhi petani untuk melakukan konversi. Pengalaman bertani yang dimiliki responden dalam mengelola usahatani jeruk, tentu akan mempermudah mereka untuk memulai dan mengelola usahatani kopi.

Hasil penelitian ini sejalan dengan penelitian Straka dan Tuzova (2016) yang menyampaikan bahwa konversi lahan usahatani di Czech Republik, dipengaruhi oleh faktor demografi dan faktor sosial ekonomi yaitu; indeks pendididikan yang menggambarkan tingkat pengalaman petani.

Kemudian faktor sosial tingkat pendidikan dan kesehatan menjadi alasan bagi $10 \%$ responden untuk melakukan konversi usaha dari usahatani jeruk ke usahatani kopi di Kecamatan
Barusjahe Kabupaten Karo. 10\% responden menyatakan bahwa faktor sosial yaitu kesehatan menyebabkan petani melakukan konversi usahatani dari jeruk ke usahatani kopi, dimana mengelola usahatani jeruk jauh lebih capek jika dibandingkan dengan mengelola usahatani kopi.

\subsection{Faktor Ekonomi Yang Mempengaruhi Konversi Usahatani Jeruk ke Usahatani Kopi di Kecamatan Barusjahe Kabupaten Karo}

Hasil penelitian juga menunjukkan petani responden melakukan konversi usahatani jeruk ke usahatani kopi didasari oleh faktor ekonomi sebagaimana disajikan pada Tabel 9.

Tabel 9. Pendapat Responden Tentang Faktor Ekonomi Sebagai Faktor yang Mempengaruhi Konversi Usahatani Jeruk ke Usahatani Kopi di Kecamatan Barusjahe 2017

\begin{tabular}{llrr}
\hline No & Faktor Ekonomi & Jumlah responden & Persentase $(\%)$ \\
\hline 1 & Kebutuhan (kontinuitas pendapatan petani) & 5 & 16,67 \\
\hline 2 & Harga & 10 & 33,33 \\
\hline 3 & Biaya produksi & 6 & 20 \\
\hline 4 & Laba/ keuntungan & 9 & 30 \\
\hline Jumlah & 30 & 100 \\
\hline
\end{tabular}

Sumber : Data Primer, diolah, 2017

Berdasarkan Tabel 9 dapat dijelaskan bahwa $33,33 \%$ responden memilih faktor ekonomi yaitu harga sebagai alasan untuk melakukan konversi dari usahatani jeruk ke usahatani kopi. Harga yang dimaksud oleh responden adalah tingkat harga jual produksi kopi yang lebih tinggi dan lebih stabil dipasaran jika dibandingkan dengan harga jual produksi jeruk di Kecamatan Barusjahe. Disamping itu $30 \%$ responden menjadikan faktor ekonomi yaitu laba/keuntungan sebagai faktor ekonomi bagi petani untuk melakukan konversi dari usahatani jeruk ke usahatani kopi. Disamping karena harga yang lebih stabil dan menjanjikan maka laba/keuntungan yang didapatkan petani dari usahatani kopi akan lebih tinggi dan stabil sepanjang tahun.

Hasil penelitian ini sejalan dengan penelitian yang dilakukan Nguyen et al (2016), yang menyampaikan bahwa konversi lahan di Hanoi Vietnaam dipengaruhi oleh faktor ekonomi yaitu pertambahan investasi dibidang pertanian yang pada akhirnya berdampak pada pertambahan pendapatan masyarakat. 
Tabel 9 juga menunjukkan 20\% responden memilih biaya produksi sebagai salah satu faktor ekonomi, yang mengakibatkan petani melakukan konversi dari usahatani jeruk ke usahatani kopi. Dimana rata-rata biaya produksi usahatani kopi lebih rendah jika dibandingkan dengan rata-rata biaya produksi usahatani jeruk diwilayah ini.

Kemudian $16,67 \%$ responden memilih kebutuhan sebagai faktor ekonomi yang menyebabkan petani melakukan konversi usahatani jeruk ke usahatani kopi. Pendapatan petani yang bersumber dari usahatani kopi lebih bersifat kontinu, karena proses panen bisa berlangsung lebih dari enam bulan dalam satu tahun, sedangkan usahatani jeruk masa panennya bersifat musiman pada sepanjang tahun.

Hasil penelitian ini sesuai dengan temuan Shaban (2014) yang menyampaikan bahwa disamping sikap petani, terdapat faktor ekonomi yaitu ekspektasi ekonomi, yang merupakan harapan akan perubahan pendapatan petani melalui keberlangsungan usahatani mereka, sebagai salah satu alasan petani dalam melakukan konversi usahatani di Jalur Gaja Palestina. Hasil penelitian ini juga didukung dengan penelitian Karki, et al (2013), di Nepal, yang menyampaikan bahwa petani melakukan konversi usahatani untuk memperoleh pendapatan yang lebih baik pada masa mendatang.

\subsection{Faktor Teknis Pemeliharaan Yang Mempengaruhi Konversi Usahatani Jeruk ke Usahatani Kopi di Kecamatan Barusjahe Kabupaten Karo}

Hasil penelitian ini menunjukkan petani responden melakukan konversi usahatani jeruk ke usahatani kopi juga didasari oleh faktor teknis pemeliharaan tanaman sebagaimana disajikan pada Tabel 10.

Tabel 10. Pendapat Responden Tentang Faktor Teknis Pemeliharaan Sebagai Faktor yang Mempengaruhi Konversi Usahatani Jeruk ke Usahatani Kopi di Kecamatan Barusjahe 2017

\begin{tabular}{llll}
\hline No & Faktor Teknis Budidaya & Jumlah Reponden & Persentase (\%) \\
\hline 1 & Hama dan Penyakit & 13 & $43,33 \%$ \\
\hline 2 & Pemeliharaan & 17 & $56,67 \%$ \\
\hline Jumlah & 30 & $100 \%$ \\
\hline
\end{tabular}

Sumber : Data Primer, diolah 2017

Berdasarkan Tabel 10, diketahui bahwa $56,67 \%$ petani responden memilih teknis pemeliharaan sebagai faktor teknis budadaya yang menyebabkan petani melakukan konversi dari usahatani jeruk ke usahatani kopi. Proses pemeliharaan usahatani jeruk yang tidak mudah (rumit), mulai dari penanaman benih yang membutuhkan perhatian yang ekstra karena sangat rentan terhadap serangan penyakit tanaman. Penanaman bibit jeruk harus dilakukan pengontrolan dan dikarbet agar terlindung dari serangan penyakit. Sedangkan proses pemeliharaan tanaman kopi cenderung lebih mudah karena tidak perlu penanganan khusus pada proses penawaran, disamping karena tanaman kopi lebih resisten terhadap serangan penyakit tanaman di Kecamatan Barusjahe Kabupaten Karo.

Tabel 10 juga menunjukkan $43,33 \%$ petani responden memilih 
adanya serangan hama dan penyakit tanaman sebagai faktor teknis pemeliharaan yang menyebabkan petani melakukan konversi dari usahatani jeruk ke usahatani kopi diwilayah ini. Petani responden menyampaikan gejala hama dan penyakit lebih rentan terjadi pada usahatani jeruk.

Jenis hama dan penyakit tanaman jeruk misalnya; a) kutu daun, umumnya menyerang bagian tunas muda dan bunga, b) kutu loncat, umunya menyerang bagian tangkai, kuncup, tunas, daun muda, c) lalat buah, umumnya menyerang buah muda hingga buah yang hampir masak, d) busuk buah, umumnya menyerang bagian buah, e) tungau, umumnya menyerang tangkai, daun dan buah, dan f) semut yang bisa menyebabkan batang berlobang dan daun berguguran, sehingga perlu dilakukan penyemprotan insektisida.

Hasil penelitian ini sejalan dengan penelitian Asadollahpour et, al (2014) yang menyampaikan bahwa petani melakukan konversi usahatani di Mazandaran Iran karena usahatani tersebut rendah penggunaan pestisida, insektisida dan penggunaan pupuk, yang mengakibatkan penurunan biaya produksi dan akhirnya pendapatan petani meningkat.

\section{KESIMPULAN DAN SARAN}

\section{Kesimpulan}

Berdasarkan hasil penelitian dan pembahasan maka dapat disimpulkan sebagai berikut; 1) biaya produksi ratarata usahatani jeruk Rp. 9.762.640/ha/tahun lebih tinggi dari Biaya produksi rata-rata usahatani kopi Rp. 5.141.837/ ha/ tahun. Dan rata-rata tingkat pendapatan usahatani jeruk sebesar Rp.14.867.110/ha/tahun, lebih kecil dibandingkan dengan rata-rata pendapatan petani dari usahaani kopi yaitu Rp.17.675.996/ha/tahun, serta tingkat efisiensi usahatani jeruk dengan nilai $\mathrm{R} / \mathrm{C}$ 2,52 lebih rendah jika dibandingkan dengan tingkat efisiensi usahatani jeruk dengan nilai $\mathrm{R} / \mathrm{C}$ sebesar 4,43 di Kecamatan Barusjahe Kabupaten Karo, 2) Faktor sosial yaitu pengakuan publik merupakan alasan utama dari $33 \%$ petani responden dan alokasi waktu untuk kegiatan adat-istiadat sebesar 26,67 \% untuk melakukan konversi sebagian lahan usahatani jeruknya menjadi usahatani kopi di Kecamatan Barusjahe Kabupaten Karo. Sementara Faktor Ekonomi yaitu harga merupakan alasan utama dari 33,3\% reponden, dan keuntungan $30 \%$, yang menjadi alasan petani responden melakukan konversi dari usahatani jeruk ke usahatani kopi. Serta faktor teknis pemeliharaan, yaitu proses pemeliharaan sebagai alasan utama bagi $56,67 \%$ petani melakukan konversi dari usahatani jeruk ke usahatani kopi di Kecamatan Barusjahe Kabupaten Karo.

\section{Saran}

Berdasarkan kesimpulan, maka saran yang dapat disampaikan adalah; 1) agar pemerintah melakukan penyuluhan yang bersifat kontinu bagi petani usahatani kopi sehingga petani dapat meningkatkan produksi usahatani dengan baik, 2) agar petani usahatani jeruk melakukan pemeliharaan dan perawatan yang lebih baik agar produksi usahatani jeruk lebih optimal sehingga pendapatan petani dari usahatani jeruk lebih baik, 3) agar petani melakukan penggunaan pestisida sesuai dengan dosis anjuran, sehingga biaya pembelian pestisida yang dikeluarkan petani bisa diminimalkan, 4) agar petani memperhatiakan konsep pertanian berkelanjutan dalam melakukan konversi lahan dari usahaani jeruk ke usahaani kopi di Kecamatan Barusjahe sehingga pendapatan petani dari 
usahatani usahatani jeruk dan usahatani kopi dapat berkesinambungan.

\section{DAFTAR PUSTAKA}

Asadollahpour, Ali., Maryam Omidi Najafabadi., Seyed Jamal Hosseini. 2014. Factors Affecting The Conversion to Organic Farming in Iran: A Case Study of Mazandaran Rice Producers.

Sci.Int.(Lahore),26(4), 1665-

1670,2014 ISSN 1013-5316; CODEN: SINTE 8.

Barati, A.A., Asadi, A., Kalantari, K.,Azadi, $\mathrm{H}$ and Witlox, F.2015. Agricultural Land Conversion in Northwest Iran. Int. J. Environ. Res., 9(1):281290, Winter 2015. ISSN: $1735-$ 6865.

BPS, 2016. Kabupaten Karo Dalam Angka. Badan Pusat Statistika Kabupaten Karo. Kabanjahe.

BPS, 2016. Kecamatan Barusjahe Dalam Angka. Badan Pusat Statistika Kecamatan Barusjahe. Barusjahe.

Dwipradnyana, I Made Mahadi., Wayan Windia., I Made Sudarma. 2015. Faktor-faktor yang Mempengaruhi Konversi Lahan serta Dampaknya Terhadap Kesejahteraan Petani: Kasus di Subak Jadi, Kecamatan Kediri, Kabupaten Tabanan. Jurnal Manajemen Agribisnis Vol. 3, No. 1, Mei 2015 ISSN: 23550759 .

Home, Robert; Elke Ries, Anna Tschanz, Annina Indermühle, 2015. Social Factors in The Decision by Swiss Farmers to Convert to Organic Farming. Acta Fytotechn. Zootechn. Vol.18,
2015 (Special Issue): 154-156.

Slovak University of Agriculture in Nitra.

Karki, Lokendra., Rosa Schleenbecker., Ulrich Hamm. 2011. Factors Influencing a Conversion to Organic Farming in Nepalese Tea Farms. Journal of Agriculture and Rural Development in the Tropics and Subtropics. Vol. 112 No. 2 (2011) 113-123. urn:nbn:de:hebis:342012011740355 ISSN: 16129830 - journal online: www.jarts.info.

Kusuma, 2006. Dampak Manajemen Laba Terhadap Relevansi Informasi. Akuntansi: Bukti Empiris dari Indonesia. Jurnal Akuntansi dan Keuangan, Vol. 8.

Lubis, 2010. Ilmu Usahatani. Bandung: Penerbit Alumni

Nguyen Thi Ha Thanh, Van Tuan Tran, Quang Thanh Bui, Quang Huy Man, Timo de Vries Walter, 2016. Socio-Economic Effects of Agricultural Land Conversion for Urban Development: Case Study of Hanoi, Vietnam. Journal Land Use Policy. 54. 583-592. Journalhomepage: www.elsevier.com/locate/landu sepol.

Salikin, K. A, 2003. Sistem Pertanian Berkelanjutan. Yogyakarta: Kanisius.

Shaban, Ahmed Abu. 2014. Factors Influencing Farmers' Decision to Shift to Organic Farming: The Case of Gaza Strip. British Journal of Economics, Management \& Trade 5(1): 78- 
8. Article No.

BJEMT.2015.006. ISSN: 2278098X. Sciencedomain. international. $\quad w w w$. sciencedomain.org.

Soekartawi. 2003. Analisis Usahatani.Jakarta: UI Press.

Straka, Jakub and Tuzova Marcela, 2016. Factors Affecting Development of Rural Areas in the Czech Republic: A Literature Review. ProcediaSocial and Behavioral Sciences $220 \quad$ (2016) $496-505.19^{\text {th }}$ International Conference Enterprise and Competitive Environment 2016, ECE 2016,
1011. March 2016, Brno, Czech Republic.

Tambunan, Tulus T.H. 2003. Perkembangan Sektor Pertanian di Indonesia, Beberapa Isu Penting. Jakarta: Ghalia Indonesia.

Thamrin, Syahruni., Slamet Hartono., Dwidjono Hadi Darwanto., Jamhari. 2015. Efisiensi Teknis Usahatani Kopi Arabika di Kabupaten Enrekang (The Technical Efficiency of Arabica Coffee Farming in the District Enrekang). Jurnal Ilmu Pertanian. Vol. 18 No.2, 2015 : 92-97. 